\title{
EXPERIMENTAL STUDY OF MUNICIPAL SOLID WASTE (MSW) LANDFILLS AND NON- AUTHORIZED WASTE DAMPS IMPACT ON THE ENVIRONMENT
}

\author{
Veronica Tarbaeva \\ Dmitry Delarov \\ Committee on Natural Resources of Leningrad region, Russia
}

\begin{abstract}
A purpose was an analysis of waste disposal sites existing in the Leningrad region and a choice of facilities potentially suitable for the removal and utilization of greenhouse- and other gases. In order to achieve the purpose in view, data were collected on the arrangement of non-authorized landfills and waste dumps within the Leningrad region. The preliminary visual evaluation and instrumental monitoring were carried out for 10 facilities. The evaluation of greenhouse- and other gas emissions into the atmosphere as well as of ground water pollution near places of waste disposal was performed. A databank was created for waste disposal sites where it could be possible to organize the work on removing and utilizing of greenhouse gas.
\end{abstract}

The conducted examination stated that landfills exert negative influence on the environment in the form of emissions into the atmosphere and impurities penetrating underground and surface water. A volume of greenhouse gas emissions calculated in units of $\mathrm{CO}_{2}$ - equivalent from different projects fluctuates from 63.8 to $8091.4 \mathrm{t}$ in units of $\mathrm{CO}_{2}$ - equivalent. Maximum summarized emissions of greenhouse gases in units of $\mathrm{CO}_{2}$ - equivalent were stated for MSW landfills of the towns of Kirishi, Novaya Ladoga and Slantsy, as well as for MSW landfills near Lepsari residential settlement and the town of Vyborg.

\section{KEYWORDS}

Non-authorized waste dumps, MSW landfills, greenhouse gases, atmospheric air pollution, instrumental monitoring.

\section{INTRODUCTION}

Sanitary cleaning of residential places and treatment of municipal solid waste (MSW) is one of the basic environmental problems in the Russian Federation. Throughout a year up to $530000 \mathrm{t}$ of MSW are formed and disposed to non-authorized waste dumps and sanitary landfills in Leningrad region [1]. Waste dumps are not only an epidemiologic danger; they inevitable become a powerful source of biological contamination and represent the hazard of ground and surface water pollution. Waste dumps and sanitary landfills discharge poisonous gases into the atmosphere. Altogether more than hundred toxic substances from waste penetrate into the environment. In many cases waste dumps burn discharging poisonous fumes into the atmosphere. Anaerobic (without air access) decomposition of organic waste is accompanied with the formation of explosive biogas which can represent a hazard for a 
human being, harmfully influencing green plants and poisoning water and air [2]. Moreover, methane as a main component of landfill gas is acknowledged to be one of culprits of the greenhouse effect origination [3].

Committee on natural resources of Leningrad region and Russian Geoecological Center carried out scientific investigation in 2007-2009. Tasks of the studies were:

- Analysis of waste disposal sites existing in the Leningrad region and a choice of objects potentially suitable for the removal and utilization of greenhouse- and other gases;

- Drawing up inventories and evaluation of waste disposal sites in the Leningrad region as sources of greenhouse- and other gas emissions and the creation of an electronic databank. Drawing up inventories of greenhouse- and other gas emissions at waste disposal sites in the Leningrad region.

- Preliminary visual evaluation of waste disposal sites potentially suitable for the removal and utilization of greenhouse- and other gases; ecological certificates of inspected waste dumps were drawn up.

- Instrumental control of waste disposal sites; evaluation of greenhouse- and other gas emissions into the atmosphere; evaluation of ground water pollution near chosen places of waste disposal.

- Work out recommendations for the program of measures to be taken on the liquidation of non-authorized waste dumps and the rehabilitation of the environment at places of their arrangement.

- On the basis of this work a geological information system (GIS) of waste disposal sites as sources of greenhouse- and other gases emissions was elaborated; electronic databanks were organized on the basis of analytical studies performed.

\section{MATERIALS AND METHODS}

289 MSW waste dumps and landfills within the territory of the Leningrad region were studied. In the course of data collecting approximate locations and areas of landfills were determined, as well as the character and prevailing type of waste. Collecting data about MSW dumps and landfills was conducted through official requests directed to administrations of the Leningrad region municipal formations, official requests to district sanitary bodies, as well as with the help of data submitted by TSGSEN (State Sanitary- and Epidemiological Authority) of the Leningrad region and by studying mass media information and sites of the World Wide Web. In order to determine facilities coordinates according to the descriptive affixment, cartographic specialists determined facilities locations and put them on the map of the Leningrad region on scale 1:1000000.

An area occupied by waste dumps, a volume, a type of accumulated waste and a type of compostible components are of great importance with the respect to the gas formation process. Biogas quantity which can be collected and utilized at dumps and MSW landfills is directly proportional to weight of dumped waste. Preliminary visual evaluation of waste disposal sites located within the territory of the Leningrad region was performed in order to choose facilities potentially acceptable for greenhouse gas collection and utilization. A visual examination was conducted at waste dumps and MSW landfills located in Kingiseppsky, Gatchinsky, Vokhovsky, Kirovsky, Volosovsky, Vsevolozhsky, Kirishsky, Vyborgsky, Slantsevsky, Priozersky, Tikhvinsky and Boxitogorsky districts of the Leningrad region. Totally 30 facilities were examined for which ecological certificates were issued. Ranking was carried out according to three basic criteria of potential gas formation, i.e. accumulated waste volume, waste morphological composition and waste storage duration - on the basis of 
the visual control and archive data. 10 facilities were chose for instrument monitoring of greenhouse- and other gases emissions

To evaluate an actual level of greenhouse- and other gases emissions into the atmosphere at sites of waste disposal, air sampling was carried out. Sampling with the purpose to determine greenhouse- and other gases concentrations was in three stages: winter, spring ( 2 samples for each facility) and summer seasons (6 samples for each facility). Sampling of greenhouse- and waste dump gases at waste disposal sites was conducted in conformity with $R D$ 52.04.186-89, GOST 17.2.3.01-86, GOST 12.2.4.02-81, as well as according to the recommendations set $[4,5,6]$. The analysis of greenhouse- and other gases concentration in air samples was conducted by procedures presented in Table 1 .

Table 1.Procedures of air samples analysis

\begin{tabular}{|c|c|c|}
\hline Nos & Components & $\begin{array}{c}\text { Methods of analysis, normative documents for } \\
\text { measuring procedures (MVI) }\end{array}$ \\
\hline 1 & Toluene & \multirow{11}{*}{$\begin{array}{l}\text { Chromato- gas-spectrometric method. «Methodical } \\
\text { recommendations on the analysis of objects of } \\
\text { unknown composition by methods of chromato- mass- } \\
\text { spectrometry, gas- and high-efficiency liquid } \\
\text { chromatography, atomic absorption spectrometry, } \\
\text { mass spectrometry with inductively-coupled plasma" } \\
\text { [5] }\end{array}$} \\
\hline 2 & Ethyl benzene & \\
\hline 3 & m, $p-$ Xylene, $o-$ Xylene & \\
\hline 5 & $C_{3}-$ benzene & \\
\hline 6 & $\begin{array}{l}\text { Non-methane volatile } \\
\text { components: ethane }\end{array}$ & \\
\hline 7 & Propane & \\
\hline 8 & Butane & \\
\hline 9 & Sulphur hexafluoride & \\
\hline 10 & $\begin{array}{l}\text { CFC and their derivatives (as } \\
\text { per trichlorofluormethane) }\end{array}$ & \\
\hline 11 & $\begin{array}{l}\text { Hydrofluorocarbons (as per } \\
\text { trifluoromethane) }\end{array}$ & \\
\hline 12 & $\begin{array}{l}\text { Perfluorocarbons (as per } \\
\text { tetrafluoromethane) }\end{array}$ & \\
\hline 13 & $\begin{array}{l}\text { Nitrogen dioxide, Nitrogen } \\
\text { oxide }\end{array}$ & Photometric, RD 52.04.186-89 \\
\hline 15 & Carbon oxide & Chromatographic, RD 52.04.186-89 \\
\hline 16 & Carbon dioxide & [5] \\
\hline 17 & Methane & Gas- chromatographic, ChD 1.456.445 MI \\
\hline 18 & Ozone & [5] \\
\hline
\end{tabular}

Analysis of obtained data of instrument monitoring of greenhouse- and other gas composition and concentration in winter, spring and summer seasons showed that macrocomponents of waste dump gas at 10 inspected objects are methane $\left(\mathrm{CH}_{4}\right)$ and carbon dioxide $\left(\mathrm{CO}_{2}\right)$ and their ratio fluctuates from $40-70 \%$ to $30-60 \%$ accordingly. In significantly lesser concentrations, at the level of the first per cents there are as a rule present: nitrogen $\left(\mathrm{N}_{2}\right)$, oxygen $\left(\mathrm{O}_{2}\right)$ and hydrogen $\left(\mathrm{H}_{2}\right)$. Various organic compounds were found as trace elements in the composition of dump gases at inspected waste disposal sites.

The evaluation of biogas streams released into the atmosphere (in conformity with SP 11-10297) is performed on the basis of the determination of rate of gas emission into the atmosphere. From a number of methods used for emission evaluation the chamber-statistical method of the determination of gas (F) emission from soils is used most frequently. In case of its application $F$ value is calculated proceeding from the following ratios: 


$$
F=\frac{C_{t}-C_{0}}{T} \cdot \frac{V}{S}=\frac{C_{t}-C_{0}}{t} \cdot h
$$

where: $C_{\mathrm{t}}$ is concentration of gas being evaluated in time moment " $\mathrm{t}$ ";

$C_{0}$ is initial gas concentration in a chamber at $\mathrm{t}=0$;

$S$ is a chamber area;

$V$ is a chamber volume;

$h$ is a chamber height;

$t$ is exposure time.

The most frequently used $\mathrm{F}$ dimensionality is $\mathrm{g} / \mathrm{m}^{2}$ per day, i.e. quantity in grams of gas released into the atmosphere per day from one square meter of an area being measured. In conformity with the above-mentioned method and on the basis of instrumental monitoring, calculations of greenhouse gas volumes were carried out for 10 waste treatment facilities.

\section{RESULTS AND DISCUSSION}

Analysis of waste disposal sites existing in the Leningrad region showed that maximum quantity of non-authorized dumps is located in Vsevolozhsky, Gatchinsky, and Lomonosovsky districts of the Leningrad region what can be explained with both the relative proximity to Saint-Petersburg and extremely unfavorable situation with household waste sanitary treatment and utilization in districts of large-scale development of gardening farms. 10 of 30 observed facilities were chose as objects potentially suitable for the removal and utilization of greenhouse- and other gases.

Analysis of obtained data of instrument monitoring of greenhouse- and other gas composition and concentration showed that MSW landfill of Kirishi town and municipal dumps of the towns Volkhov, Novaya Ladoga and Slantsy are characterized by the maximum intensity of biogas emissions.

According to measurement data and gas emission calculations, recorded values of gas emissions into the atmosphere for $\mathrm{CO}_{2}$ (from 0.31 to $2.04 \mathrm{~g} / \mathrm{m}^{2}$ per day), $\mathrm{CH}_{4}$ (from 0.53 to $17.7 \mathrm{~g} / \mathrm{m}^{2}$ per day) and $\mathrm{N}_{2} \mathrm{O}$ (from 0.001 to $0.022 \mathrm{~g} / \mathrm{m}^{2}$ per day) correspond to a range characteristic for gas generating technogenic structures. In conditions making difficult unloading of gas generating systems into the atmosphere such emission can cause the accumulation of waste dump gas concentrations. Table 2 presents data on emissions of dump gas main components, i.e. carbon dioxide and methane and summary emissions in units of $\mathrm{CO}_{2}$ - equivalent at inspected waste dumps and MSW landfills. Emission volumes are given in tones per year per a facility area. In the lower part of the Table a mean index is given of emissions from an area unit of inspected facilities. In the course of the calculation of $\mathrm{CO}_{2}-$ equivalent summarized value, a coefficient of global warming for $\mathrm{CH}_{4}$ equal to 21 was used, for $\mathrm{N}_{2} \mathrm{O}-310$. This coefficient adopted by РКИК (Kyoto Protocol to the Framework Convention on Climate Change) means that the emission of 1 tone of methane is equivalent to the emission of $21 \mathrm{t}$ of $\mathrm{CO}_{2}$ and $1 \mathrm{t}$ of nitrogen oxide is equivalent to the emission of $310 \mathrm{t}$ of $\mathrm{CO}_{2}$ 
Table 2. Emissions'volumes of dump gas from MSW landfills and waste dumps

\begin{tabular}{|c|c|c|c|c|c|}
\hline \multirow[b]{2}{*}{ Objects being evaluated } & \multirow[b]{2}{*}{$\begin{array}{c}\text { Area, } \\
\text { hectares }\end{array}$} & \multicolumn{3}{|c|}{ Emissions' volumes, t/year } & \multirow{2}{*}{$\begin{array}{c}\mathrm{CO}_{2} \\
\text { equivalent } \\
\text { summarized } \\
\text { value, } \\
\text { t/year }\end{array}$} \\
\hline & & $\begin{array}{l}\text { Carbon } \\
\text { dioxide }\end{array}$ & Methane & $\begin{array}{l}\text { Nitrogen } \\
\text { oxide }\end{array}$ & \\
\hline $\begin{array}{l}\text { Waste dump, Slantsy, } 400 \mathrm{~m} \text { to } \\
\text { west from the village of Pechourki }\end{array}$ & 4,3 & 31,7 & 137,2 & 0,03 & 2921,5 \\
\hline $\begin{array}{l}\text { Waste dump, Volkhov, to } \\
\text { northeast of Mourmanskiye } \\
\text { Vorota industrial zone }\end{array}$ & 6,5 & 30,5 & 3,8 & 0,07 & 130,8 \\
\hline $\begin{array}{l}\text { Waste dump, Priozersk, } 0.5 \mathrm{~km} \text { to } \\
\text { northeast from the town of } \\
\text { Priozersk }\end{array}$ & 4,8 & 9,9 & 48,8 & 0,03 & 1043,6 \\
\hline $\begin{array}{l}\text { MSW landfill, the city of Vyborg, } \\
\text { near the settlement of Tamisuo }\end{array}$ & 8,3 & 9,4 & 89,1 & 0,66 & 2084,7 \\
\hline $\begin{array}{l}\text { Waste dump, Gatchina, } 300 \mathrm{~m} \\
\text { from settlement of Ivanovka }\end{array}$ & 7,2 & 48,3 & 12,2 & 0,22 & 372,9 \\
\hline $\begin{array}{l}\text { Waste dump, Kingisepp, } 2 \mathrm{~km} \text { to } \\
\text { the north from the town of } \\
\text { Kingisepp }\end{array}$ & 8,2 & 48,9 & 15,5 & 0,01 & 377,4 \\
\hline $\begin{array}{l}\text { MSW landfill, Kirishi, } 15 \mathrm{~km} \text { to } \\
\text { north from the town of Kirishi }\end{array}$ & 6,0 & 26,0 & 382,6 & 0,15 & 8105,2 \\
\hline $\begin{array}{l}\text { Waste dump, Kirovsk, the } 5^{\text {th }} \mathrm{km} \\
\text { of Kirovsk-Mga motor road }\end{array}$ & 8,7 & 57,3 & 2,6 & 0,03 & 122,2 \\
\hline $\begin{array}{l}\text { MSW landfill, Lepsari, } 1.5 \mathrm{~km} \text { to } \\
\text { east from the village of Lepsari }\end{array}$ & 6,9 & 51,4 & 99,5 & 0,14 & 2184,6 \\
\hline $\begin{array}{l}\text { Waste dump, Novaya Ladoga, the } \\
3^{r d} \mathrm{~km} \text { of Novaya Ladoga- } \\
\text { Chernoushevo motor road }\end{array}$ & 4,8 & 26,4 & 124,9 & 0,05 & 2664,9 \\
\hline \multirow{3}{*}{ Statistics: } & Min & 9,4 & 2,6 & 0,03 & 122,2 \\
\hline & $\operatorname{Max}$ & 57,3 & 382,6 & 0,66 & 8105,2 \\
\hline & $\begin{array}{l}\text { Mean per } 1 \\
\text { ha }\end{array}$ & 5,3 & 14,1 & 0,02 & 307,8 \\
\hline
\end{tabular}

The table analysis shows that the largest methane emissions at inspected facilities are observed within the territory of MSW landfill of Kirishi (up to 382.6 tones of methane per a year), municipal dumps of Slantsy and Novaya Ladoga and landfills of Lepsari and Vyborg. Minimum values of methane emissions are observed at dumps of Kirovsk and Volkhov (2.6 и 3.8 tpa correspondingly). A mean value of methane summarized emission per 1 unit of area of inspected facilities is 14.1 tpa. Carbon dioxide emissions from inspected facilities fluctuate from 0.03 to 0.66 tpa. The largest emissions of carbon dioxide are recorded at the Kirovsk waste dump, at MSW landfill of Lepsari and at waste dumps of the towns Kingisepp and Gatchina. A mean value of carbon dioxide summarized emission per 1 unit of area of inspected facilities is 5.3 tpa. 
Nitrogen oxide emissions are insignificant and fluctuate from 9.4 to 57.3 tpa at inspected facilities. Maximum emissions of nitrogen oxide are recorded at the following facilities: MSW landfills of Vyborg and Kirishi, resident settlement Lepsari and at a waste dump of Gatchina. A mean value of carbon dioxide summarized emission per 1 unit of area of inspected facilities is 0.02 tpa. Summarized volumes of greenhouse gas emissions calculated in units of $\mathrm{CO}_{2}$-equivalent fluctuate from 122.2 to 8105.2 tones in units of $\mathrm{CO}_{2}$ - equivalent. An average value of emissions in units of $\mathrm{CO}_{2}$ - equivalent per 1 hectare of a territory of dumped mass is equal to 307.8 tpa. The largest summarized emissions of greenhouse gases in units of $\mathrm{CO}_{2}$ - equivalent are revealed for the MSW landfill of Kirishi, municipal waste dumps of Novaya Ladoga and Slantsy, as well as the MSW landfill of Lepsari settlement and the Vyborg town.

MSW landfills of Kirishi, Vyborg and Lepsari and municipal waste dumps of towns of Novaya Ladoga and Slantsy have high potential (more than $10 \%$ emissions of total summarized volume of emissions from inspected facilities and methane predominance in dump gas) for dump gas collection.

\section{PROPOSITIONS TO PLAN OF MEASURES ON LIQUIDATION OF NON-SANCTIONED WASTE DUMPS AND THE ENVIRONMENT REHABILITATION AT PLACES OF THEIR LOCATION}

With the purpose to struggle with non-sanctioned waste dumps in Leningrad region, it is necessary to develop a strategy of handling waste in the region defining the main purpose and the general plan of activities for a short-time, mean-time and long-time periods [2]. This plan offers to include the following proposals on liquidating non-sanctioned waste dumps and the rehabilitation of the environment:

\section{Technical measures}

1. Drawing up an inventory of unsanctioned waste dumps within the whole territory of the Leningrad region, permanent upgrading the database and the control of facilities' state dynamics.

2. Liquidating non-sanctioned waste dumps, carrying out the timely recultivation of land, which was disturbed in result of contamination with MSW and other waste and making impossible the repeated formation of spontaneous dumps. The following stage-after-stage variant of actions is offered as an example:

- Liquidating a waste dump, i.e. direct garbage disposal;

- Filling the territory with soil;

- The territory improvement: on places of former dumps trees and bushes are planted: chestnut, birch-tree, mountain ash and lilac;

- The installation of agitation posters.

3. The installation of containers at places of non-sanctioned waste dumps permanent formation. The coordination with specialized organizations collecting and disposing waste. Communal authorities should sign contracts on MSW disposal with residents of private sectors. If inhabitants refuse to do so to compel them signing contracts on MSW disposal by order of the court. 


\section{Administrative and legal measures}

1. The development and realization of programs of MSW utilization and reprocessing within the territory of the region, stipulating drawing investments into the construction of facilities of MSW treatment, including:

- Designing, constructing and renovating of landfills for disposing any kinds of waste.

- Designing, constructing, renovating and updating of production plants (workshops, industrial mills), meeting current environmental requirements for reprocessing, sorting and incinerating of any types of waste [1,2].

4. Bringing waste disposal and burial facilities to the conformity with environmental and sanitation requirements and their updating, including ownerless facilities.

5. Strengthening of control over municipal enterprises exploiting MSW burial places. They should work according to developed technologies and projects.

6. Strengthening of state authorities' control over industrial and agricultural waste kept at production sites. The information on waste storage conditions, on measures of their neutralization, reprocessing and use is incomplete. Reliable and objective data on waste types, volumes of their formation and accumulation, their movement, demand and the possibility of their using as secondary raw materials are frequently lacking.

7. The stimulation of waste minimization, utilization and reprocessing by enterprises. The development of regional scientifically substantiated measures of MSW control and the creation of systems of collection, transportation, storage and recording of MSW.

8. Recommending to directors of municipal formations to arrange the cooperation with managers of enterprises of different forms of the ownership on the liquidation of spontaneous waste dumps, cleaning territories and cleaning cesspools.

9. Furnishing municipal formations with full powers and increasing of financial resources for them within the sphere of handling production and consumption waste. Administrations of municipal formations should insert into official regulations the persons authorized to draw up administrative protocols for violation of the territory improvement rules, to foresee the responsibility of working in this direction and introduce a record system. Appoint responsible persons in municipal formations.

10. Local authorities should ensure the fulfillment of requirements of regional laws "On producing amenities", including as follows: to adopt rules (decisions) regulating in their territory the activity on the land improvement and waste handling; to appoint administrative commissions authorized to consider affairs of administrative infringements of the law within the sphere of producing amenities, to determine a list of official persons controlling the activity directed on the land improvement and authorized to draw up protocols of administrative infringements of the law when adopted rules are violated.

11. In order to put a stop to the formation of non-sanctioned dumps of MSW and other waste, to organize at the level of local authorities and municipal formation administrations:

- permanent checks by official persons aiming to reveal garbage piles in their territories. Drawing up administrative protocols for guilty persons;

- control of land improvement rules observance at objects of construction or buildings renovation;

- control of sanitary norms and rules observance in the course of domestic waste collection at container sites eliminating container overfilling and garbage piles beside them. 
12. The elaboration of a special document at the level of local authorities in which obligations are set forth for all organizations involved in sanitary cleaning of a residential place and controlling waste handling norms and rules observance. The observance of this document will allow liquidating non-sanctioned dumps in territories of local authorities and preventing their formation.

13. Stimulating the work of district militia officers in the control of non-sanctioned regional MSW dumps formation (article 387 of the RK Code of administrative infringements).

14. The increase of penalty sanctions with respect to legal and physical persons for violations of environment protection laws.

15. Drawing up inhabitants to the struggle against non-sanctioned waste dumps. Installation of telephones at environment protection departments for urgent messages from citizens who are not indifferent to the problem of spontaneous dumps and who became witnesses of waste unloading at an unforeseen place. Official persons should arrange checking of each message.

16. The arrangement of .unpaid work performed collectively on a Saturday and during a month.

17. The proposal to the Leningrad region public prosecutor to specially control the cases of unsanctioned waste disposal within the territory of the Leningrad region and take decisive measures to detect guilty persons.

\section{Popularization of environmental problems}

1. Publishing in mass media the information both about violations of rules and norms of waste handling by residents and about the positive experience of local authorities in problems of the sanitary treatment. It will help to increase a level of the population environmental culture.

2. Work with educational institutions:

- The arrangement of school environmental patrols. Patrolling and mapping of nonsanctioned waste dumps.

- Conducting young people actions on cleaning of spontaneous dumps and trashed places.

3. The arrangement of photographic exhibitions, environmental conferences, environmental competitions (e.g. an environmental poster competition, a competition of social- and environmental advertising, a competition on drawing the public attention to the waste problem), scientific and practical seminars and conferences (ecological grants) at all levels of the state power.

\section{CONCLUSIONS}

Obtained results of the studies conducted were stated that waste dumps exert negative influence on the environment in form of emissions into the atmospheric air and polluting substances contaminating underground and surface water. At municipal dumps of Novaya Ladoga, Priozersk, Gatchina, Kingisepp, Kirovsk and landfills of Kirishi and Lepsari TLVs of residential places air were surpassed as for a number of volatile organic compounds, i.e. toluene, ethyl benzene and xylenes. Maximum concentrations of volatile organic contaminants in atmospheric air were recorded within the territory of the MSW landfill of Kirishi.

Results of the investigations of greenhouse and other gases showed that the main macrocomponents of dump gas of inspected facilities are methane $\left(\mathrm{CH}_{4}\right)$ and carbon dioxide $\left(\mathrm{CO}_{2}\right)$ and make $99 \%$ of waste dump gas, and their ratio fluctuates from $40-70 \%$ to $30-60 \%$ 
accordingly. Nitrogen $\left(\mathrm{N}_{2}\right)$, oxygen $\left(\mathrm{O}_{2}\right)$ and hydrogen $\left(\mathrm{H}_{2}\right)$ are available as a rule in much smaller concentrations, at the level of the first per cents. Gas emissions into the atmosphere for $\mathrm{CO}_{2}$ (from 0.31 to $2.04 \mathrm{~g} / \mathrm{m}^{2}$ per day), $\mathrm{CH}_{4}$ (from 0.53 to $17.7 \mathrm{~g} / \mathrm{m}^{2}$ per day) and $\mathrm{N}_{2} \mathrm{O}$ (from 0.001 to $0.022 \mathrm{~g} / \mathrm{m}^{2}$ per day) correspond to a range characteristic for technogenic gas generating structures. The largest methane emissions at the inspected facilities are observed in the territory of MSW landfill near the Kirishi town (up to 382.6 tones of methane per year), municipal dumps of the towns of Slantsy and Novaya Ladoga, as well as landfills of Lepsari and Vyborg. Carbon dioxide emissions at inspected facilities fluctuate from 9.4 to 57.3 tpa. Maximum emissions of carbon dioxide are found out at the following facilities: the waste dump near Kirovsk, MSW landfill of Lepsari and waste dumps of Kingisepp and Gatchina.

The summarized volume of greenhouse gases calculated in units of $\mathrm{CO}_{2}$-equivalent fluctuates from 122.2 to 8105.2 tones in units of $\mathrm{CO}_{2}$-equivalent. A mean value of emissions in units of $\mathrm{CO}_{2}$-equivalent per 1 hectare of a dump territory is equal to 307.8 tpa. The largest summarized emissions of greenhouse gases in units of $\mathrm{CO}_{2}$-equivalent are recorded for MSW landfill near the town of Kirishi, municipal dumps near the towns of Novaya Ladoga and Slantsy, as well as MSW landfills of Lepsari and Vyborg. It is noted that summarized emissions from inspected facilities as per units of $\mathrm{CO}_{2}$ - equivalent are by an order lower than single facilities of a fuel- and power complex, e.g. of a heat-electric generation plant using coal or diesel fuel.

Thus, in result of conducted studies it was stated that waste dumps exert moderate negative influence on the environment in the form of emissions into the atmospheric air and contaminating substances getting into underground and surface water.Greenhouse gas emissions from inspected facilities are relatively small, and only for the largest facilities with a high quota of compostible waste (e.g. MSW landfill near the town of Kirishi) there exists a possibility of the realization of projects directed for the reduction of dump gas emissions and attracting the attention of investors, both Russian and foreign ones. It is noted that the costs spent for the creation of biogas collection and utilization systems at waste dumps and MSW landfills of the Leningrad region are non- comparable with the environmental effect obtained from the reduction of summarized emissions of greenhouse gases for a constituent territory of the Federation.

\section{REFERENCES}

[1] Tarbaeva V.M., Savenkova G.B. 2004. Analysis of legislation in waste management in Saint-Petersburg and Leningrad region. In: Proceedings of international conf.: Instrumentation in ecology and human safety, November 10-12, 2004, S-Peterburg, Russia, pp.181-184

[2] Tarbaeva V.M., Lebed O.S. 2004. Current state and perspectives of international cooperation in the field of waste management in Saint-Petersburg and Leningrad region. In: Proceedings of international conf.: Instrumentation in ecology and human safety, November 10-12, 2004, S-Peterburg, Russia, pp.25-31

[3] Tarbaeva V.M. 2004. Russia is ready to ratification of Kiyto protocol. Mir StroyIndustrii. N 21, 55-56

[4] Starobnits I.S., Kalinko M.K. 1985. Sampling and analysis of natural gases of oil- and gas basins Moscow, Nedra.

[5] Handbook of practical methods and control of uncertainty in the national recording of greenhouse gases. 1999. MGEIK.

[6] Instruction on drawing up inventory and national recording of greenhouse gas emissions (a project). 2005. Saint-Petersburg, "NII Atmosphere". 